\title{
Implications of Lifelong Education Training Management Program
}

\author{
Tika Santika \\ Nonformal Education Program \\ FKIP of University of Singaperbangsa Karawang \\ Jl. HS. Ronggowaluyo, Telukjambe, Karawang, Indonesia \\ tikasantika_usk70@yahoo.com
}

\begin{abstract}
Lifelong education is an education system that is carried by humans from birth until death. Implementation of lifelong education in creating a learning society can give the contribution for the human resources quality. One of lifelong education implementation in nonformal education lane is through the training unit. The implementation of lifelong learning through a training program started by planning, organizing, implementation and evaluation. Management training programs must be managed effectively to achieve maximum results. The first step in managing the training program is planning. In this step, should be analyzed the training needs of institutional training needs, unity of the units within the institution or individual training needs and then plan the training programs to design the curriculum in a participatory manner with the involvement of various parties. The second step is the organizer. In this step, need to focus on communication, logistics, facilitators, participants and other supporting infrastructure. The third step is the implementation. In this step, it should be consistent with what has been planned. The last step in the management training program is the evaluation and follow-up. A lot of training that has been organized and carried out, but after that there was no follow-up again. Training evaluation and follow-up is very important to know the various shortcomings, weaknesses and strengths of training events and processes.
\end{abstract}

Keywords: Lifelong education, management, training

\section{INTRODUCTION}

Education is a process leading to maturation, to achieve optimal education required various types of education not only in formal education, but also informal and nonformal education, and then the education is a complex process in which all of an entity.

As stipulated in Law No. 20 of 2003 on National Education System [1] "That the national education system should guarantee equal educational opportunities, improving quality and relevance and efficiency of education management to face challenges in accordance with the demands for changes in local, national, and global so we need to reform the education which are planned, directed, and sustained ". Whereas in reality still has not been guaranteed the equality of education development, as well as quality improvement is still not managed properly.
Lifelong education is an education system that is carried by humans from birth until death. Implementation of lifelong education in creating a learning society to contribute in improving the quality of human resources. One application of lifelong education in nonformal education field is through the training unit.

With these problems, the training is the most appropriate way, where the above issues can be addressed. Training is a separate requirement for an individual or an organization. Training is an activity to enhance the skills, knowledges and attitudes of individual. Where most of training held based on the work needs, or any gaps with performance, because past performance is not expected or do not achieve the goal. Thus training must be designed in such a way clearly, systematically, and focus.

\section{METHOD OF STUDY}

The purpose of this study is to investigate the implications of lifelong education in training management. Method of this study is a literature review by using reference books related to training management.

\section{DISCUSSION}

\section{A. The concept of training management}

Usman [2], stated that the management according to Parker (Stoner \& Freeman, 2000) as the art of carrying out the work through other people. Meanwhile, according to Robbins and Coulter in Hermaya and Slamet [3] defines management as the process of coordinating the activities of the work efficiently and effectively. As Irawan et al [4] states that management is defined as the tips (a combination of art and science) to regulate or manage all the resources (human and nonhuman) of the organization, so that organizational goals can be achieved efficiently.

Management function is basic element that will always exist and inherent in the management process that will be used as a reference for their activities in order to achieve organizational goals. Where the management functions are systematic steps in carrying the management or operations of an organization, which generally include planning, organizing, implementation and evaluation. 
Planning of selection activities related to alternatives, policies, procedures in the program as a form of business to achieve the goals. While the organization is an action or activity that combines the existing potentials of all parts within a group of person or organization to work together in order to achieve predetermined objectives, either for personal or group goals and objectives of the organization. The implementation is the applying of planning and organizing, where all the components will work together in accordance with their respective fields in order to realize the goal. And further surveillance is an act to control all activities of the process of planning, organizing and execution, whether all these activities can provide an effective and efficient results and also be valuable and effective.

Definition of training according to Sastradipoera (2006: 122) training is one kind of learning to acquire and improve skills beside the system of human resource development prevailing in a relatively short time with the method which is more practice than theory.

While Hamalik (2005: 10) argues that training is a management function that needs to be carried out continuously in order to develop people in organization. Specifically, the training process is a series of actions carried out continuously, gradually, and integrated.

There are three of training program components which should be concerned; input, process, and output. As well as education, where the input is a student, then in training inputs are participants. The training process can be run effectively and efficiently, if supported by the availability of the advanced trainer that is widiaswara/instructor/coach, as well as the availability of infrastructure, training materials and others. While the outputs from the training are increased knowledge, skills and better attitude changes.

By looking at the description above can be concluded that the training is a systematic effort in building and developing of participants who can cover the development of knowledge, skills and work attitudes so that participants can perform their duties and roles optimally to achieve organizational goals.

While in the training process proposed by Mathis and Jackson in Angelica [5] states that there are four systematic training process, namely: assessment, design, delivery, and evaluation.

\section{1) Planning}

Planning of training is intended to help organizations of participants in achieving the goals. According to Mathis and Jackson in Angelica [5] that the priority objectives of the training should be determined by identifying the gap analysis which indicates the distance between the location of the organizational capabilities and employees. Objectives and training priorities are determined to close the gap. There are three types of training objectives can be determined as follows: (1) knowledge that embed cognitive information and details for participants, (2) the skill, developing behavioral changes in doing obligations of work and tasks, (3) attitudes, creating interest and awareness of the importance of training.

Thus the assessment of the needs of the organization is an early diagnostic of determining a destination training.

\section{2) Organizing}

Integrating human resources and nonhumans who needed into a single unit to carry out activities in achieving the goals. In other words, the organization is the process of managerial activities to form organization with carrying out a predetermined plan to achieve organizational goals [6]. The organization emphasizes the dynamic interaction between the people in it. The importance of interaction based on the theory and empirical experience shows human relationship can influence the activities of the organization.

\section{3) Implementation}

The next step of training that has been developed by the training centers is the implementation of the training process. But according to Mathis and Jackson in Angelica [5] training should be tested in advance or implemented in an experiment to ensure the training meets the needs which are identified and appropriated design.

From the above opinion, before the actual training process implemented, it should try to have training experiment to find out the results of the identification of training needs and planning has been fulfilled in accordance with expectations to achieve the training objectives or not.

For the purpose in this second step, adult learning models can achieve the training objectives. Thus the learning activities are needed to design a training environment that suits adults' character, and should choose a method, integrated teaching and learning strategies and training techniques carefully, systematically training materials, conduct an inventory of environmental resources that can be exploited, entirely should refer to the research objectives. It is a direct function in the process of learning activities that facilitate event activities for the participants.

The process of effective training will be able to realize the improvement and enhancement of knowledge, skills / expertises and attitude of the participants. The implementation of the training should be able to choose a relevant training model, the training can be applied well. The implementation of good training as one form of training program management processes in order to improve the quality of human resources. Absolutely in the enactment of training programs should be conducted in earnest.

\section{4) Evaluation}

According to Ralph Tyler in Robert O. Brinkerhoff (1983: xiv) defined evaluation: evaluation as the process of determining to extent the educational objectives are actually being realized ". Meanwhile, according to Farida Alkin [6] Joseph Tayibnafis stated that evaluation is a process of convincing decision, choosing the right information, collecting and analyzing information so that it can report a summary of useful data for decision makers in choosing some alternatives. While Farida [7] states that the evaluation program is intended to provide better data about various things are related to the characteristics and appearance.

From the above statement can be interpreted that the purpose of the evaluation is a process to assess the activities of the training program. This step is not only evaluating the achievement of learning for participants, but also the overall 
evaluation of the training program. Evaluation of training programs can be conducted in a variety of activities. It can be evaluated by before, during, and after the training. So from the results of evaluation can be known, what the advantages and disadvantages of process training programs that have been implemented. So that the evaluation will be used as management policy of training center for the next training program.

\section{B. The implications of lifelong education in trainingmanagement}

Kamil [8] developed a ten-step management of the training are:

\section{1) Recruitment of participants}

In Recruitment of participants, the organizer of the training set several requirements that must be met by the participants, especially relating to the characteristics of the participants to follow the training.

\section{2) Identification of learning needs}

Learning resources, and obstacles of needs assessment. Identifying the learning needs is an activity to search, find, record, and manage data on the learning need which is desired or expected by a participant or organization.

\section{3) Determining and formulating training goals}

Training objectives are formulated to lead training event from beginning to the end, started by learning development and evaluation planning. For that purpose the formulation of training must be conducted carefully.

4) Preparing assessment tools for the initial test and final evaluation

An initial evaluation determines "entry behavioral level", while the final evaluation is intended to measure the level of acceptance of the material by the participants as well as to know the material that needs to be deepened and improved.

\section{5) Collating sequence of training activities}

At this stage the training provider determines study materials, select and define the methods, learning techniques, as well as specify the media to be used. The sequence of activities that must be considered: the participant, learning resources, time, facilities available, forms of training, and training materials.

\section{6) Training for trainers}

Coaches must understand the overall training program, the sequence of activities, scope, training materials, methods, and media. It should be understood correctly by the coach. Therefore, the orientation of coach is very important to do.

\section{7) Carrying out an evaluation for participants}

An initial evaluation of the initial evaluation, can be conducted by spoken or written test.

\section{8) Training implementation}

This phase is the core of the training activities, which is a process of educational interaction between the learning resources with learners to achieve the goals.

9) Final evaluation
This phase is conducted to determine the learning success of the participants, the organizer would like to know absorption and acceptance of learners to the various materials that have been submitted. Furthermore, the organizer can determine the steps for the next time.

\section{0) Program evaluation}

Evaluation of the training program is to assess the activities of all the activities from the beginning to the last, and the result will be the input for the development of further training.

A good training can achieve the goals that have been defined previously, and contribute greatly to solve problems in the reality, and can improve the work appearance of participants. Usman [2], states that management is very needed in the process of education and research, in order to achieve these following:

- Realization of active, creative, effective, enjoyable and meaningful training atmosphere.

- Developing participants who are actively enhancing his potential to have the spiritual power of religion, selfcontrol, personality, intelligence, character, and skills are needed for themselves, society, and nation.

- The achievement of training objectives effectively and efficiently.

- Issues of quality education and trainingcan be addresed, because $80 \%$ of the quality problems, caused by the management.

Furthermore, the importance of management training besides implementing management functions. Management also plays a role in the success of the training process, so that management training is expected to provide support to the participants, before conducting training, where management meets with prospective participants and inform training purposes as well as what they expected; support in training, the presence of management within the training also gives impact in terms of motivating the participants during the learning; As a support after implementing the training, managements meet the participants and ask about their responses, implementation in their work and supporting from the management.

Function of training management is a component of the training system, each component is managed by the principles of management functions, so that the training can be conducted well and reach the goals. Because of that reason, scope of management functions can be divided into two activities. First; administrative management which is also called the field of management of administrative functions, i.e., activities to lead everyone in the organization / group can work together doing the right things to achieve the goals. Second; operative management, field of this activity is also called management of operative function, that is activity which has the purpose to lead and develop everyone doing the job properly and correctly.

\section{CONCLUSION}

The implementation of lifelong learning through a training program begins the planning, organizing, and implementation 
to evaluation. Management training programs must be managed effectively to achieve maximum results.

Training is a systematic effort as the guiding and developing of participants who cover the development of knowledge, skills and work attitudes so that participants can perform their duties and roles optimally to achieve organizational goal.

\section{REFERENCES}

[1] Undang-Undang Nomor 20 Tahun 2003, Sistem Pendidikan Nasional, Jakarta; Cipta Grafika

[2] Usman, Husaini. 2011. Manajemen Teori, Praktik, dan Riset Pendidikan. Jakarta: Bumi Aksara

[3] Hermaya, T dan Harry Slamet. 2004. Manajemen. Klaten: Intan Sejati

[4] Irawan, Prasetya, dkk. 1997. Manajemen Sumber Daya Manusia. Jakarta: STIA-LAN

[5] Angelica, Dian. 2006. Human Resource Management. Jakarta: Salemba Empat

[6] Sudjana, D. 2004. Manajemen Program Pendidikan. Bandung: Falah Production

[7] Farida. 2000. Evaluasi Program. Jakarta: Rhineka Cipta

[8] Kamil, Mustofa. 2010. Model Pendidikan dan Pelatihan Konsep dan Aplikasi. Bandung Alfabeta 